\title{
National Instability and Personal Identity Crisis in Stephen Karam's Sons of the Prophet
}

\author{
Sahar Mokbel
}

\begin{abstract}
Sons of The Prophet, the 2012 Pulitzer Prize winner play, written by the brilliant young LebaneseAmerican playwright Stephen Karam, speaks of the physical and spiritual sufferings of Joseph Douaihy and his family members. Karam's play, which stems from Khalil Gibran's book The Prophet, traces the changes that occurred to the generations following Gibran. The family that descends from a Lebanese origin fades as each member fails to identify a fixed national and personal identity. The play ends with endless pain overwhelming the Douaihys and turning them into a disabled family.
\end{abstract}

Index Terms - Crisis, hybridity, identity, nationality, pain.

\section{INTRODUCTION}

Nationality is the combination of national identification, psychology, and outlook; it is associated with language, family, custom, and parental psychology [1]. The stability of one's national identity is thus linked to every aspect of his life. On the other hand, the rise of national instability can be linked to hybridity. Joseph M. defines hybridity as "a democratic expression of multiple affiliations of cultural citizenship" [2]; however, multiple citizenships lead to national instability and personal identity crisis. This is the state of Joseph Douaihy and his family who appear as a disabled family torn between two nations and two identities.

Upon leaving Orphalese, the Prophet says: "It is not a garment I cast off this day, but a skin that I tear with my own hands" [3]. It is obvious that Orphalese, though not his native country, has become a part of the Prophet's identity. That was the case of Gibran who left his mother country and resided in the United States, but what would be the state of those who were born outside their native country? Where do they belong? What are their sufferings? And would the sufferings of their mother country become the bases of their pain?

Sons of the Prophet comes to remind us of the unforgettable The Prophet. In his division of the play scenes, Stephen Karam uses the same sub-titles that Gibran Khalil Gibran has spoken of in his great book The Prophet. Therefore, Karam's choice of the title cannot be separated either from Gibran's book or from the truth that Karam's play is based on the aspects that Gibran has tackled earlier.

\section{BoDY}

Manuscript received February 6, 2015; revised July 23, 2015.

S. M. is with the English Department, Lebanese University, Lebanon (e-mail: saharmokbel@hotmail.com).
Gibran says: "Your children are not your children. They are the sons and daughters of Life's longing for itself" [3]. In Karam's play, the sons of The Prophet appear as a disabled family suffering from physical as well as spiritual torture. In the first scene, entitled "On Work", Karam presents his protagonist Joseph Douaihy, who, similar to the author, has been born in the United States. Both hold the American citizenship but the Arabic family name. The scene begins with Gloria and Joseph discussing the Middle East issues at the office where Joseph works. Gloria, with a newspaper in hand, seems concerned with what is happening in Lebanon more than Joseph:

Gloria: Well because of... I heard about the bombing of the Lebanese airport, the civilian casualties - have you not seen the news?

Joseph: No, I mean, I've caught bits and pieces of it on $\mathrm{TV}, /$ but

Gloria: And that's exactly what Beirut's been reduced to again, isn't it—bits and pieces, God...so much suffering in that part of the world...[4].

In this scene, Joseph appears to be lost; he wants to leave the office early. Gloria mentions the sufferings of Joseph's native country and links his present state with that of his country. Joseph's words "bits and pieces" present that he cares little about what is going on right there, but Gloria uses Joseph's words to describe Beirut that has been reduced into 'bits and pieces'. What Gloria is trying to show, Joseph is trying to hide. It is the truth that the sufferings of a nation are inseparable from the sufferings of its children.

Gloria's words are teasing; she adds: "I don't know how the Lebanese are able to endure so much pain, it never ends for them, does it? .... I'm sure that your family agrees that Israel's, their desire to defeat Hamas is so / untenable-". Gloria mentions 'pain'; the Lebanese face endless pain; she also mentions Joseph's family, for she aims at showing that this pain is that of all Lebanese people whether they were living inside their nation or outside of it. At this time, he asks her: "Did someone tell you I'm Lebanese?"[4]. Joseph's hybrid identity cannot be hidden, for his family name 'Douaihy' is not a common name as Gloria says. But, why did Karam stress on Joseph's name and nationality? It seems that when speaking about the sufferings of a person, one needs to highlight on all forms of suffering, and Joseph's national identity crisis just adds to his pain. Aleinikoff argues that multiple attachments lead to compartmentalizing people's lives into separate spheres [5]; this will lead to national instability, as is the case of Joseph.

In the same scene and throughout their speech, Gloria deduces that Joseph is the brother of the "former champion Charles Douaihy". She not only mentions Charles but also mentions his disability; a matter which confuses Joseph who 
prefers not to discuss his family problems in the office:

Gloria: The point of the matter is just that you shouldn't feel shy about discussing 'your family / in the office.

Joseph: When I'm in the office I just don't like to discuss / my personal life.

Gloria: You're brother's disability [4].

Joseph's brother is disabled, a fact that adds to the sufferings of his family. What about Joseph? He too suffers from knee problems: "I think I tore my meniscus" he says. As we go through the play, it becomes obvious that every member in Joseph's family suffers from physical illness. The physical sufferings are apparent, so Joseph can hide nothing of it. What is more painful to Joseph lies in the spiritual conflicts that he tries to keep as secrets as much as possible. However, Gloria tries to reveal all Joseph's secrets she adds saying:

Gloria: "You are a blood relative of Khalil Jibran!-The best-selling author of all time behind Shakespeare and Lao Tzu!

Joseph: No, no no-we're distantly related, as in our great great grandfathers/ were cousins-

Gloria: I don't care if he's your grandfather's fifth cousin removed - Gibran's name sells books — why would you hide this from me?

Joseph: I wasn't hiding anything-Gloria, I am Lebanese. And my parents were born in Bsharri, but what's the extent of my Arabian heritage. Look at me, I'm white. We were born and raised in Pennsylvania. We're white [4].

Gloria resembles the American voice; she will never let Joseph rest. The reason lies in his national identity crisis; an identity that Joseph fails to identify. Joseph, who was born and raised in Pennsylvania, tries to convince himself, first, that he is detached from his origins. However, Gloria's curiosity to know everything about him adds to his suffering. She is just reminding him of the fact that he cannot deny: the truth behind his hybrid identity. Therefore, he confesses that he is Lebanese by origin, but pretends not to be affected by his Arabic heritage. He mentions the color of his skin; as if his 'white' skin color is the mask that he tries to use in order to hide his Lebanese origin. It is, thus, obvious that Joseph's problems and sufferings stem from his inability of identifying the nation that he truly belongs to.

Gibran, the great Lebanese writer, who too was Lebanese-American, appears to be 'a blood relative' of Joseph, a matter that shall turn Joseph to be proud of such a heritage, for Gibran himself was proud of his Arabic heritage. Here lies the question: why does not Joseph act similar to Gibran and be proud of his origins. The fact lies in that each belongs to a different generation. With the passage of time, being of an Arab origin living in the United States would just add problems to Joseph regardless of the greatness of his ancestors. Arab-Americans have started to struggle because of their roots since September 11 for they were "suddenly confronted with the double pain of mourning an attack on their country and simultaneously having to defend themselves, their families, and their stature as Americans" [6]. (Arab American Institute, Healing The Nation)

Gloria wants to uncover everything related to Joseph's family and ancestors; she has the chance now to speak of Joseph's father:
Gloria: Precisely. The whole meaning of The Prophet according to Gibran is: "You are far, far greater than you know, and/ All is well."

Joseph: All is well, I know. My father says that all the time.

(Beat. Gloria senses Joseph doesn't want to continue the dialogue, but can't help herself)

Gloria: In Arabic, or does he speak /English---

Joseph: I need to get going,/ I'm sorry-

Gloria: Of course, no I'm sorry, look why don't you just ask your father if he'd be willing to-

Joseph: My father is in the hospital. He was in a car accident [4].

'All is well' are words that have been usually uttered by Joseph's father. This shows the influence of Gibran on the father who had suffered too before his death, so who is well? None of the family members is physically fine. Their physical illness is definitely symbolic, for it actually symbolizes their spiritual sufferings that result from their unstable identity. Gloria cares for whether the father spoke in Arabic or in English only to prove for Joseph that they are influenced by their Arabic heritage. Joseph, on the other hand, rejects Gloria's idea of writing a book about his family history saying: "My family is very protective of their history. They'd never agree to a book about their past. It's a bad idea." But Gloria knows very well that Joseph's rejection of her idea comes as a result of the family sufferings. She tells Joseph: "It's more than knee pain you've got" [4] hinting on his spiritual suffering rather than the physical one. The scene ends with Gloria insisting on the idea of writing a 'book' while Joseph trying to escape the situation. This act of escape reveals Joseph's inner conflict and fear of facing the truth of something painful he is trying to hide.

'Pain', on which Gibran has said: "Your pain is the breaking of the shell that encloses your understanding,"[3] becomes the title of the second scene in Karam's play. Although the title is adopted from Gibran's book, yet the pain Joseph's family is suffering from can hardly enclose their understanding. The actions now take place at the doctor's office where Joseph appears with two of his family members: his uncle Bill and his brother Charles. With the Physician's Assistant on one hand and two of his family members on the other, Joseph's inner struggle becomes clearer as he tries once again to conceal more truths about his family; however, with the presence of Charles, things become even worse:

Charles: Our father died-

Joseph: Charles-

Charles: It's not a secret, relax

Bill: Okay all right..

Physician's Assistant: I'm sorry to hear that.

Charles: Thank you.

Bill: Hypo-what, doc? You were saying-

Joseph: Uncle Bill, can you let me do the talking, sorryjust ...(To the Physician's assistant.) just talk to me please... [4].

As the family members speak, each one contradicts the other. Joseph wants to be the only speaker believing that Charles and Bill would reveal the secrets of his family, but who can silence Uncle Bill or Charles? The scars of the 
family are thus revealed; the father is dead, Joseph has severe knee pain, Charles cannot hear well since he is born with one ear and the uncle uses a wheel chair and has other health problems [7] (Wallenberg, Misery and Company). Bill, then, recalls Gibran's words: "The most massive characters are seared with scars" [4], as if saying that the sufferings of the family are to be accepted, but Charles utters the ultimate truth: "We are turning into the disabled family"[4]. This truth makes Joseph embarrassed; he wishes to conceal everything but the truth can never be buried.

The conflict taking place turns to be between two different generations. Bill's beliefs and national identity are still linked with his mother country, with the Arabic heritage and with what he has learned earlier from his family members; hence, he suffers without complaining. On the other hand, both Charles and Joseph are lost; they are unable to identify their new national identity, as they try to prove their disconnection with their Arabic heritage and beliefs.

Bill: How about the picture of St. Rafka, did you leave that up?

Joseph: Yeah. Charles... Charles: No.

Charles: He'd find out when he comes over. Bill: Why not? Put it back up-

Joseph: She's on her death bed, Uncle Bill, she has no eyes in the photo-

Charles: Her suffering is what's beautiful about it [4].

'Faith' here plays an important role in showing how the old generation, represented by the Uncle, still have faith. Uncle Bill's faith is a part of his national identity, for he had inherited his beliefs from his ancestors and declares that they are Maronites, 'Mwarneh'; on the contrary, Joseph and Charles show carelessness towards their religious heritage. Thus, Charles adds: "We stopped going to church", but the reason lies in the main problem; it is diaspora: "You want to know real suffering, take a look at your blood line, the Maronites of the Diaspora gave their lives for your/ faith [4](Karam, 27). Charles is sharp and direct; he does not try to hide the truth of his sufferings as Joseph does. He, therefore, sheds the light on the main problem he and Joseph are facing; it is diaspora that results from the loss of one's national identity. Charles and Joseph, then, cannot accept what they have inherited for they consider their 'grandparents sound like clowns'. If the ancestors become similar to clowns; then, will Joseph and Charles be able to adopt a new national identity without struggle?

Karam, then, takes us to the third scene of the play 'On Talking' of which Gibran has said: "And there are those who talk, and without knowledge or forethought reveal a truth which they themselves do not understand." [3] The words of Gibran are truly everlasting, and what Joseph is revealing through his words is a truth that he cannot understand.

With the appearance of Timothy, a reporter, Joseph is once again trapped by his family name. 'Douaihy' gives Joseph an identity that he cannot truly identify with or even understand:

Timothy: No I was just gonna ask what kind of name is Douaihy?

Joseph: Off the record,/ yes?

Timothy: Of course off the record, yes...

Joseph: It's Lebanese. We're supposedly descended from, from French knights in Douai, France [4].

Joseph's Lebanese origin becomes the major point that Timothy tries to speak about. Joseph, who reveals that he had never been in Lebanon, declares that he speaks some Arabic phrases that he had learned from his father. In fact, persons who are familiar with the Arab culture and history are aware that the Arabs tend to identify with their ancestral place of origin regardless of where they were born or raised [8]. Despite the fact that Joseph had never been in Lebanon, it is evident that the seeds of his grandfathers are inherent in him and definitely affect his identity: "I used to have this image of my grandfather as this kinda woeful, uneducated guy - now I'm like: the skills he had-three languages, a practical trade, made extra money as a tailor-I went to college and the only marketable skill I have is stuff I knew before college" [4]. Upon comparing himself with his grandfather, it is obvious that Joseph considers himself as a failure, for he was not able to be similar to his ancestors. He, who represents the modern educated generation, has failed in contributing to the wealth of his family history, turning, therefore, with his brother Charles to be 'two gay grandsons' and the 'end of the line' as Joseph says. Joseph's words, then, had summarized the whole conflict the new lost generation is suffering from. He is the end of the line because not only he will not breed, but also his identity crisis has limited his abilities; he, the one connected with Gibran, the 'gold mine', turns to be a suffering character living in a 'suffering world' [4].

Moving toward the forth scene of the play 'On Home', the incidents take place at the Douaihy's house. On homes, Gibran asks: "Have you peace, the quite urge that reveals your power? ...Or have you comfort, and the lust for comfort?" He then adds: "Your house shall be not an anchor but a mast. It shall not be a glistening film that covers a wound, but an eyelid that guards the eye." [3] Gibran, then, had defined the role of the house; it shall bring comfort and peace, but it shall not be a tool for covering one's wounds. However, in Karam's play, the Douaihy's house appears to be tool for hiding the wounds rather than a space for comfort and relaxation. This appears through the successive conflicts that take place among the different family members.

A new character, Vin, appears in this scene; he is the boy who was responsible for the car accident through which the father had died. Vin has been raised with a foster family; thus, according to Uncle Bill, he is similar to 'a fish out of water'. Uncle Bill, then, sheds the light on the problem of identity; a problem that he himself had faced upon coming to the United States: "my father moved us here penniless... and we grew up sleeping on mattresses". Joseph and Charles become annoyed by hearing their Uncle speaking this way; they want him to stay silent so and to listen to Vin; however, in this family, no one is ready to hear the other because no one is able to understand the other:

Bill: ...we didn't wait for handouts when we arrived here, /but today there's pockets of immigrants...

Charles: Oh my God..

Bill: I'm not saying hard work isn't in their blood, but now they expect a free ride-ESL programs, Mexican parade--

Joseph: Uncle Bill, let Vin- 
Bill: ----all our tax dollars---I'm just saying that keeps happening, what's the identity of America going to be? [4].

Despite the conflict raised among the different family members, the identity of America turns to be a debatable issue. America has 'Lebanon at its center' says Joseph. Literally, this is true because right in the middle of Kansas lays a town called Lebanon. Symbolically, America's identity is affected by its inhabitants; on the other hand, the Lebanese who live in America carry a hybrid identity; i. e., the Lebanese American identity. The family's debate shows once again the importance of their national identity which is torn between two nations.

The Douaihys are then interrupted with an unexpected guest, 'Gloria', whose idea of writing a book about Joseph's family makes her curious to know every single truth about the family:

Gloria: This is the cover and title of our book. Gibran is the Prophet. You're the focus but your father, brother, uncle, all the, all of the Mennonite/ descendants-

Joseph: Maronite-

Gloria: --- right relatives from Lebanon, we could canvas the whole bloodline, hundreds of people offering new wisdom for a new day [4].

None of the family members finds the idea of the book delightful; they know their own sufferings. They, the descendants of the great Lebanese artist Gibran, have turned into a fading tragic family instead of becoming great and successful; therefore, the idea of the book will only add to their sufferings:

Joseph: Listen to me: no one will ever read this book, she's crazy,...

Bill: You're not gonna exploit family tragedy — she wants to turn us into some circus show, full of untimely deaths-

Joseph: I wouldn't let her do that ...the book will/ never make it off the ground! [4].

However, Gloria, obsessed by Joseph's family origins, wants to write her book "Sons of the Prophet" to reveal the sufferings of Joseph's family not only because they are the latest generation of Gibran's family, but also because she believes that the sufferings of this generation is linked to that of their mother country Lebanon. Therefore, she once again sheds the light on the problems taking place right there:

Gloria: Location, location, location...

Charles: Yeah, Lebanon's suffered for centuries' cause of its - (pointing to the map of Lebanon.) see how it's at the crossroads of three continents and religions and all these civilizations...

Gloria: Hamas, Hezbollah... whole thing's a /mess...

Charles: ...yeah, yeah no my grandparents ... no one's life should have to be about finding ... stability...

Gloria: Yes, but whose life isn't... everyone starts life off with a certain number of handicaps, you hear what I'm saying - oh God can you hear what I'm saying? / I didn't mean- [4].

Similar to Lebanon, the Douaihys' family lacks stability. Charles points out at the location of Lebanon. He considers its important location, in the middle of three continents, as the main reason behind its instability. Moreover, he points at the different civilizations that had passed through this country. While Charles points at the past of his country,
Gloria sheds the light on the present conflicts. Lebanon was under the Israeli attacks while Hezbollah was trying to defend the country. Gloria, not only hints at the problem Lebanon was suffering from but also links this problem with Charles disability. He, then, is handicapped and this is another reason for his crisis. Gloria's words make Charles lost and weak. He turns to be a person who seeks stability; he witnesses the pain of his country through looking at its map. He, then, adds: "Lebanon looks like a man's face, in pain, screaming...see, if you just add an eye here....?"[4] Lebanon, then, is similar to a man screaming; this man can be Charles or Joseph or any other Lebanese citizen witnessing the pain of his country. Therefore, it is evident that Charles's identity is affected by his Lebanese origin and roots. He, who represents the new Lebanese-American generation is lost in a country that can offer him everything but not a stable national identity.

In the fifth scene of the play, Joseph's body seems to be 'falling apart' as Charles says. They are both at the hospital where Joseph is examined with three unrelated diseases: inflamed knees, neuropathy, and muscle weakness Definitely, Joseph is facing ultimate physical pain, a pain that adds to his hopelessness, and thus increases his conflict with Charles. Their words become more insulting, and they turn into two upset and desperate brothers:

Joseph: Stop getting so upset-

Charles: I am upset you're having fluid drained from your spine!

Joseph: It's gonna be fine-

Charles: No it's not we have no parents... and Uncle Bill is so old, I keep hoping he dies so we can stop watching him get worse [4].

This melancholic situation and Charles' words show how the Douaihy's family has fallen apart. Gibran's statement "all is well" no more suits the present situation. "The question of why we suffer is unanswerable, but how we suffer defines our character and shapes our lives more than we care to acknowledge" says Charles Isherwood in his review of the play [9] (Isherwood, Blighted Existences). The Douaihys' sufferings had shaped their life and turned them into a disabled and a shattered family that lacks health, spiritual comfort, guidance and support.

The last two scenes of the play present each member of this tragic family fading with endless physical and spiritual pain. With Uncle Bill, on wheelchairs, speaks of the past and of the origins of his family: "because the Douaihys, we're part of history, we're gonna fade if you don't remember.../I Marune [I am Maronite] [4] His identity cannot be separated from his ancestors. He witnesses how his family has come to an end, but he too is dying slowly and lacks the ability of change.

Joseph on the other hand is annoyed once again by his visitors, Timothy and Gloria, who again to benefit from this tragic family through interfering in their private life. To Timothy, the desperate Joseph asks: "You couldn't find a family more tragic than mine to exploit?" [4] Even his friends add to his pain instead of relieving it. Timothy, in return, tries to lessen Joseph's pain by encouraging him to 'do something' that can change his way of life. However, Joseph's physical and spiritual sufferings have turned him into a pessimist who has no ambitions or dreams at all. "I'm 
not fine. I'm not fine" are Joseph's words to Timothy who cannot understand the truth of his pain. As to Gloria, the one whose presence annoys Joseph most, she comes to declare that what she had seen of the Douaihys' suffering is unbearable: " ... what the Douaihys have lost is... none of us can know....I'm here because this morning I was struck with... a sense of...not understanding" [4].

\section{CONCLUSION}

It is all then about pain, suffering and hopelessness. It is the Douahys' family that is dying tragically. The loss of stability has turned the family into 'bits and pieces'. Their tragic ending stems from that of their suffering mother country. The question of happiness, hope and optimism becomes marginalized when people's sufferings become the whole not a part of their lives. Hence, 'all is well', the statement of hope, and whose founder is Gibran, can no more find its place with all this pain overwhelming Joseph's family.

\section{ACKNOWLEDGMENT}

I would like to thank the organizing committee for accepting my paper for presentation and publication at ICCSH 2015. I would also thank the Lebanese University for encouraging and supporting researchers in any field of study. Special thanks are for my husband Dr. Salman Roumie for encouraging me to improve my work and research.

\section{REFERENCES}

[1] R. Stanley, Dual Citizenship and American National Identity, Washington, Center for Immigration Studies, 2001

[2] M. Joseph, "Introduction: New hybrid identities and performance," Performing Hybridity, University of Minnesota Press, 1999, pp. 1-24.

[3] K. Gibran, "The prophet," New Delhi, India: Sterling Publishers, 2004.

[4] K. Stephen, Sons of the Prophet, New York: Dramatists Play Service, INC. 2012.

[5] A. Alexander, "Between national and post-national: Membership in the United States," Journal of Race and Law, Michigan, 1999.

[6] Arab American Institute. Healing the nation: The Arab American experience after September 11. [Online]. Available: www.newsu.org/course_files/.../ArabAmericanExperience.pdf

[7] W. Christopher, Misery and Company, New York: American Theatre, Apr. 2011, vol. 28, p. 22.

[8] C. Louise, "Homeland insecurity: The Arab American and Muslim American experience after 9/11," Russell Sage Foundation Publications, 2011.

[9] I. Charles, "Blighted existences, eased with hope and humor," New York Times, 2011.

Sahar Mokbel is a Lebanese citizen. She was born in AlGazieh, a village in southern Lebanon, in 1983. She received her $\mathrm{Ph} . \mathrm{D}$. in English language and literature from Beirut Arab University, Lebanon in 2013

She has started teaching English literature at the Lebanese University since 2013. Previously, she used to teach English at schools since 2003. She had participated in three conferences and published three articles entitled as follows: 1) The development of the western cowboy hero in movies. presented at Annual International Conference on Language, Literature and Linguistics, Singapore, 2012; 2) The postmodern American man in sam Shepard's Curse of the Starving Class, presented at 2013 International Eurasian Academic Conference, Antalya, Turkey, 2013; 3) The loss of national identity in Sam Shepard's The God of Hell, Global Advanced Research Journal of Arts and Humanities, vol. 2, no. 5, Oct. 2013. Recently, she is interested in studying Arab American literature. 